\title{
Coronary artery disease in a young man with normal serum lipids
}

\author{
Dennis M. Krikler and Barry Lewis \\ From the Cardiac Department, The Prince of Wales's General Hospital, London; \\ and the Department of Chemical Pathology and Lipid Disorders Clinic, Royal Postgraduate \\ Medical School, London
}

A young patient is described in whom cardiac infarction occurred despite the virtual absence of the risk factors usually associated with this condition.

Coronary heart disease tends mainly to present after the age of 40 , but the incidence may be rising in younger subjects (Friedberg, 1966). So few cases occur under 30 that one should seek possible underlying metabolic or anatomical causes, which are especially evident in young patients (Heinle et al., 1969; Tzagournis et al., 1968).

\section{Case report}

The patient was born in Israel of Yemenite Jewish parents, and has lived in England since 1962. On 30 August 1968, when 23 years old, he experienced squeezing retrosternal pain for 4 hours, and was admitted to hospital. None of his family has suffered from ischaemic heart disease. He smoked to to 15 cigarettes a day and followed a conventional Western diet. He worked as a motor mechanic; there was no history of trauma to the chest.

He was $169 \mathrm{~cm}$ tall and weighed $63.5 \mathrm{~kg}$. There were no physical abnormalities on examination; the blood pressure was $120 / 70 \mathrm{mmHg}$, with no evidence of pre-existing hypertension. The peripheral pulses were normally palpable. Electrocardiograms showed the evolution of partialthickness anterolateral cardiac infarction: on the day after admission there were inverted $T$ waves in leads I, aVL, V5, and V6, and ST depression in $\mathrm{V}_{4}$ (Fig. $\mathrm{I}$ ). Urinalysis, full blood count $(\mathrm{Hb}$ $16.3 \mathrm{~g} / 100 \mathrm{ml}$ ), erythrocyte sedimentation rate, blood urea, electrolytes and proteins, and chest $x$-ray were all normal. The serum enzymes are shown in Table I.

Treatment included analgesics, rest, intravenous heparin and oral warfarin, and he stopped smoking. Over the next two weeks the abnormalities on the electrocardiogram improved, though $\mathrm{T}$ inversion in leads $\mathrm{I}$ and aVL was still present after 8 weeks. He recovered rapidly and
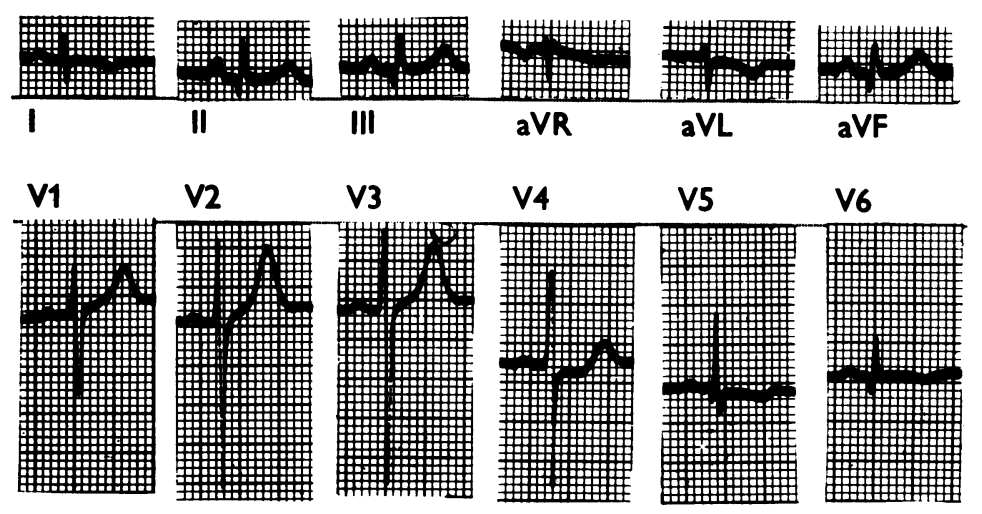

FIG. I Electrocardiogram at onset of illness, 31 August, 1968.

was discharged from hospital one month after admission. During the next 6 weeks he had several mild episodes of angina on exertion; since then he has been symptom free, and has remained normotensive (blood pressure range I05-I25/ $70-80 \mathrm{mmHg}$ ). The electrocardiogram had returned to normal after $4 \frac{1}{2}$ months, but there was

TABLE I Serum enzyme values

\begin{tabular}{lccl}
\hline & $\begin{array}{l}\text { SGOT } \\
\text { (Frankel units) }\end{array}$ & $\begin{array}{l}\text { SGPT } \\
\text { International } \\
\text { units }\end{array}$ \\
\hline 30 August & 46 & 38 & 420 \\
31 August & 100 & 35 & 675 \\
\hline
\end{tabular}


plane ST depression in postexercise tracings recorded one and two years later.

Further investigations have shown low-normal serum lipids (Table 2); on thin-layer chromato-

- graphy of plasma lipids, the ratio of ester to free cholesterol appeared within normal limits. Glu-

- cose tolerance and plasma insulin response were normal after $50 \mathrm{~g}$ glucose orally (Table 3 ). The serum uric acid was $3.3 \mathrm{mg} / 100 \mathrm{ml}$ : Wassermann reaction, lupus erythematosus cells, and antinuclear factor negative. On I4 April I970, cardiac catheterization was normal; coronary angiography

\& showed: left coronary artery-proximal narrowing of anterior descending and circumflex branches

- (Fig. 2); right artery normal, contributing collaterals to the ischaemic area.

\section{Discussion}

> The patient presented with the clinical features of cardiac infarction; this was confirmed

- by the electrocardiogram and serum enzyme changes. Subsequently further evidence of

cardiac ischaemia was obtained from the positive effort cardiograms, and occlusive coronary artery disease was demonstrated by angio\& graphy.

The importance of abnormalities of lipo-

+ protein and carbohydrate metabolism in younger subjects with coronary artery disease

$\rightarrow$ has been stressed by Heinle et al. (1969): 80 per cent of their cases aged less than 50 had hyperlipoproteinaemia (including all aged 20-29); 96 per cent had one or other abnormality. Our patient, who developed signs of ischaemic heart disease at the age of 23 , is strikingly unusual: there is no hyperlipidaemia and his glucose tolerance is normal. Furthermore, he is not obese (body weight within the

- normal range of the Metropolitan Life Insurance Co., I959), has always been physically active, has consistently had a normal blood pressure, the serum uric acid is normal, and

- there is no family history of premature vascu-

- lar disease; nor were there indications of psychological stress. Cigarette smoking was

- the only specific risk factor present (Stamler, 1971).

Not only did he not have hyperlipoproteinaemia: his serum lipid levels tended to be

- low. Furthermore, he belongs to an ethnic group in which coronary artery disease is

- relatively uncommon, whether for genetic or environmental reasons (Krikler, I970; Vlodaver, Kahn, and Neufeld, 1969). Despite this, he suffered a cardiac infarct at an extremely young age, showing no evidence of

- inflammatory arteritis, and having no signs of aortic valve disease or of an abnormal origin

- to either of his coronary arteries. Though histological proof of the diagnosis of coronary

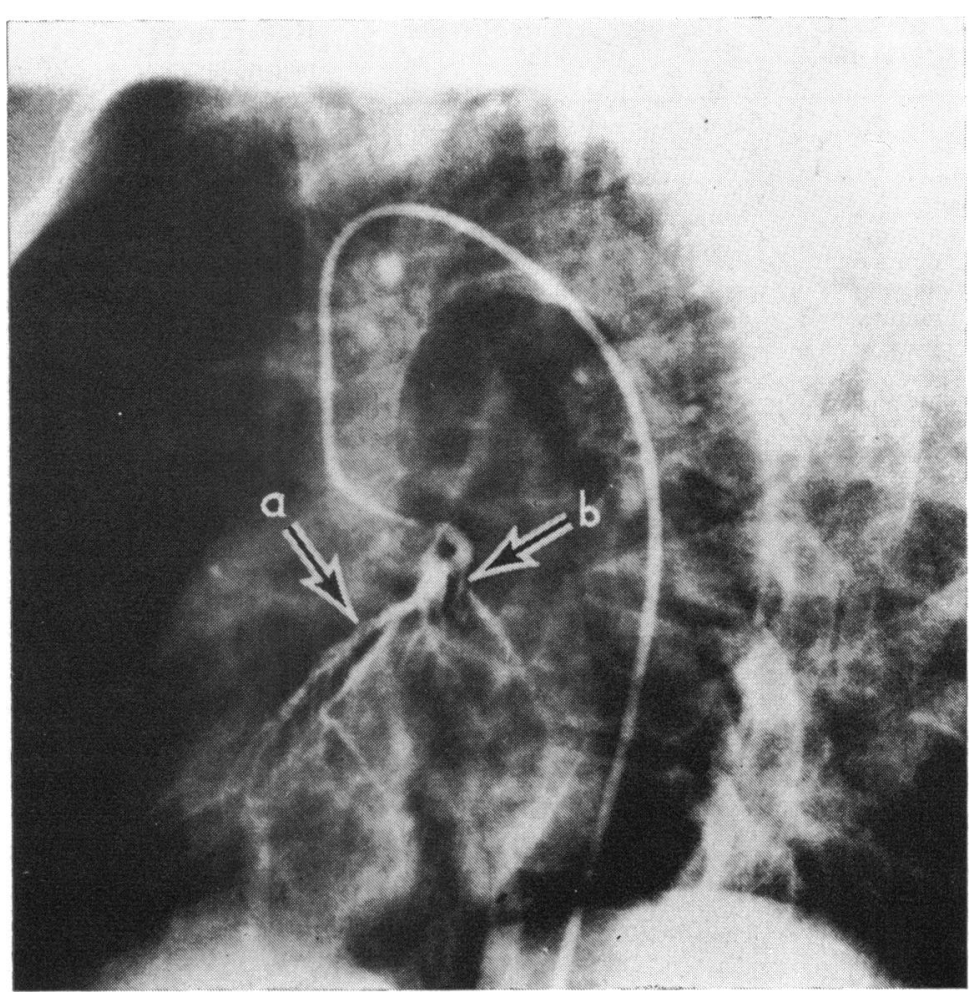

FIG. 2 Left coronary arteriogram, left

anterior oblique projection, showing (a) narrow-

ing of anterior descending branch, suggesting

recanalized thrombosis, and (b) stenosis of

circumflex branch, with poor filling distally.

TABLE 2 Plasma lipid values

\begin{tabular}{|c|c|c|c|}
\hline & $\begin{array}{l}\text { Cholesterol } \\
(\mathrm{mg} / \mathrm{I} 00 \mathrm{ml})\end{array}$ & $\begin{array}{l}\text { Triglycerides } \\
(\mathrm{mg} / \mathrm{IOO} \mathrm{ml})\end{array}$ & $\begin{array}{l}\text { Lipoprotein } \\
\text { electrophoresis }\end{array}$ \\
\hline 30 August 1968 & 125 & & \\
\hline I6 September, 1968 & 170 & & \\
\hline 7 February, 1969 & 140 & 62 & \\
\hline 17 December 1969 & 100 & 74 & Low $\beta$, no pre $-\beta$ \\
\hline Io July 1970 & 160 & 49 & $\alpha$ and $\beta$ visible \\
\hline I7 July I970 & 135 & 56 & \\
\hline
\end{tabular}

Preparative ultracentrifugation:

\begin{tabular}{|c|c|c|c|}
\hline P & & $\begin{array}{l}\text { Cholesterol } \\
(\mathrm{mg} / 100 \mathrm{ml})\end{array}$ & $\begin{array}{l}\text { Triglycerides } \\
(\mathrm{mg} / \mathrm{IOO} \mathrm{ml})\end{array}$ \\
\hline $\begin{array}{l}\text { Very low density lipoproteins } \\
\text { Low density }(\beta) \text { lipoproteins } \\
\text { High density }(\alpha) \text { lipoproteins }\end{array}$ & $\begin{array}{l}(D=\mathbf{D} \cdot 006) \\
(D=\mathbf{r} \cdot 006-\mathbf{r} \cdot 063) \\
(D=\mathbf{r} \cdot 063-\mathbf{r} \cdot \mathbf{2} \mathbf{r})\end{array}$ & $\begin{array}{r}10 \\
114 \\
49\end{array}$ & $\begin{array}{l}18 \\
21 \\
20\end{array}$ \\
\hline
\end{tabular}


TABLE 3 Glucose tolerance test and serum insulin values

\begin{tabular}{ccc}
\hline & $\begin{array}{l}\text { Blood glucose } \\
(\mathrm{mg} / \mathrm{IOO} \mathrm{ml})\end{array}$ & $\begin{array}{l}\text { Serum insulin } \\
(\mu \mathrm{U} / \mathrm{ml})\end{array}$ \\
\hline Fasting & 77 & 6 \\
30 minutes & 126 & 34 \\
60 minutes & 110 & 7 \\
90 minutes & 100 & - \\
I20 minutes & 54 & - \\
\hline
\end{tabular}

atherosclerosis is lacking, the features are otherwise quite in keeping with this diagnosis. The exceptional feature of our case is that most of the known risk factors for ischaemic heart disease were absent in a patient presenting with myocardial infarction at the age of 23.

We are grateful to Dr. D. G. Gibson and Dr. S. Rees for the cardiac catheterization and coronary arteriograms.

\section{References}

Friedberg, C. K. (1966). Diseases of the Heart, 3rd ed. W. B. Saunders, Philadelphia and London.

Heinle, R. A., Levy, R. I., Fredrickson, D. S., and Gorlin, R. (I969). Lipid and carbohydrate abnormalities in patients with angiographically documented coronary artery disease. American fournal of Cardiology, 24, 178.

Krikler, D. M. (1970). Diseases of Jews. Postgraduate Medical fournal, 46, 687.

Metropolitan Life Insurance Co. (1959). Statistical bulletin 40.

Stamler, J. (1971). Acute myocardial infarction - progress in primary prevention. British Heart fournal, 33, Suppl., 145 .

Tzagournis, M., Chiles, R., Ryan, J. M., and Skillman, T. G. (1968). Interrelationship of hyperinsulinism and hypertriglyceridemia in young patients with coronary heart disease. Circulation, 38, 1156.

Vlodaver, Z., Kahn, H. A., and Neufeld, H. N. (1969). The coronary arteries in early life in three different ethnic groups. Circulation, 39, 54I.

Requests for reprints to Dr. D. M. Krikler, The Prince of Wales's General Hospital, London Ni5 4AW. 